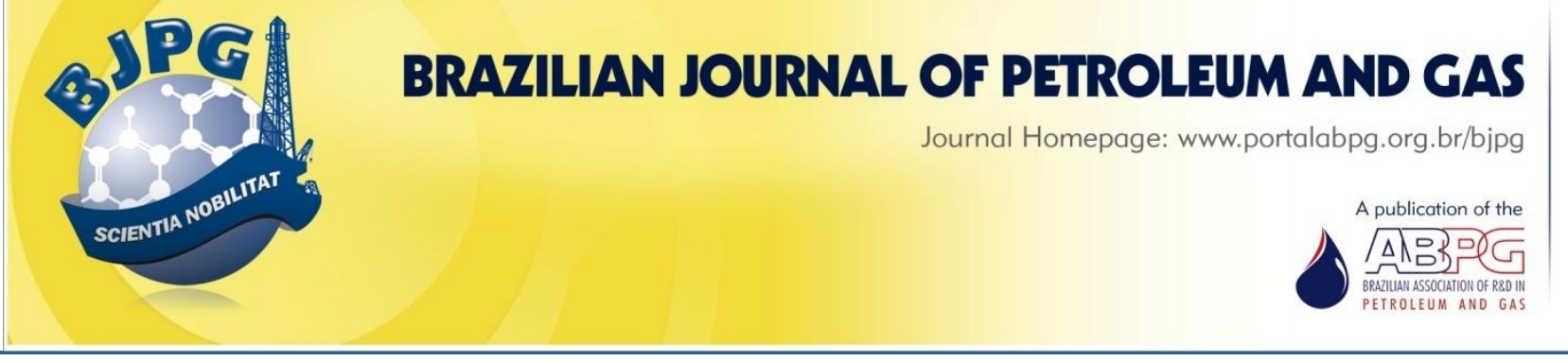

\title{
EMPIRICAL EVALUATION OF STIRRING PROCEDURES IN THE PRODUCTION OF BIODIESEL FROM CASTOR OIL
}

\author{
a Nazário, J. L.; ${ }^{a}$ Soletti, J. I.; ${ }^{a}$ Carvalho, S. H. V.; ${ }^{\text {a }}$ Delcolle, R.; ${ }^{a}$ Meili, L. ${ }^{1}$; Peiter, A. S. \\ a Laboratory of Separation Systems and Process Optimization (LASSOP), Center of Technology, Federal University of Alagoas \\ - UFAL, Maceió - AL, Brazil
}

Received: 21.01.2016 / Revised: 22.03.2016 / Accepted: 29.03.2016 / Published on line: 12.07.2016

\begin{abstract}
Aiming to evaluate how stirring procedures impact biodiesel production from castor oil, this work employed a fractional factorial design to study the influence of some parameters on the alkaline catalytic transesterification of castor oil for biodiesel production. Biodiesel was produced in a pilot plant equipped with a stirring tank reactor and a thermostatic bath. The study used a $2^{7-2}$ factorial design. The variables were stirring rate, presence or absence of deflection, impeller type, oil/methanol molar ratio, reaction time, temperature, and catalyst type. Gas chromatography afforded the reaction yields. Analysis of each variables as well as evaluation of binary interactions helped to determine how the parameters affected biodiesel production. The best conditions for a yield of $99.3 \%$ were: turbine impeller, absence of deflection in the reactor, stirring rate of $500 \mathrm{rpm}, 1: 7 \mathrm{oil} / \mathrm{alcohol} \mathrm{molar} \mathrm{ratio,} \mathrm{sodium} \mathrm{hydroxide} \mathrm{as} \mathrm{catalyst,}$ reaction time of $30 \mathrm{~min}$, and temperature of $50^{\circ} \mathrm{C}$.
\end{abstract}

\section{KEYWORDS}

experimental design; biofuel; transesterification; stirring rate; reaction

\footnotetext{
${ }^{1}$ To whom all correspondence should be addressed.

Address: Laboratory of Separation Systems and Process Optimization (LASSOP), Center of Technology, Federal University of Alagoas, Av. Lourival de Melo Mota, s/n, Tabuleiro de Martins, Maceió - AL - Brazil. ZIP Code: 57072-970 | Telephone: +55 82 3214-1292 |e-mail: lucas.meili@ctec.ufal.br doi:10.5419/bjpg2016-0007
} 


\section{INTRODUCTION}

Biodiesel is a renewable biofuel originated from various sources, such as a vegetable oil (soybean, corn, palm, and castor oils), an animal fat (beef tallow, chicken fat), and used cooking oil (Adewale et al., 2015; Sánchez et al., 2015). Compared with the petroleum-derived diesel, biodiesel generates less carbon dioxide and practically eliminates sulfur dioxide emissions. Interestingly, any diesel cycle engine can run on biodiesel, with little or no need for adaptation (Almeida et al., 2015; Çetinkaya \& Karaosmanoglu, 2004; Leung et al., 2010; Patil \& Deng, 2009; Rodríguez-Guerrero et al., 2013; Vasudevan \& Briggs, 2008).

When studying the use of oilseeds in biodiesel production, the seeds of castor beans have attracted a huge interest, for they are abundant in northeastern area of Brazil, the world's third larger producer of castor beans, accounting for $8 \%$ of the world's production in 2010/2011 (Baron et al., 2014). The amount of oil extracted from these seeds ranges between 40 and $50 \%$ in weight (Sánchez-Cantú et al., 2013). A comparison between castor oil and most vegetable oils reveals an atypical feature: it contains triglycerides of ricinoleic acid, a hydroxylated fatty acid that rarely occurs in vegetable oils, which represents between 80 to $90 \%$ of the castor oil composition (Barbosa et al., 2010; Hincapié et al., 2011; Sáez-Bastante et al., 2015; Scholz \& Silva, 2008). Despite featuring these favorable characteristics, castor oil is not considered the best raw material to produce biodiesel. Nonetheless, its study is important because the castor oil biodiesel has high viscosity and density, factors that cause undesirable outcomes, such as longer residence times, low yields, and high costs related to the use of chemicals. In general, animal fats and vegetable oils present high viscosity. Unfortunately, this characteristic prevents their direct use in engines that run on diesel (Muniyappa et al., 1996; Scholz \& Silva, 2008). Transformation of crude plant oil into esters (biodiesel) reduces the viscosity of the starting oil (Ferella et al., 2010).

Conventionally, the transesterification reaction is employed to produce biodiesel. This reaction basically consists of introducing a load of vegetable oil into a reactor coupled with a stirrer and heating system, where excess alcohols (methanol or ethanol) attack the glycerides in the presence of acid or basic catalysts (Atadashi et al., 2013; Knothe et al., 2005; Motasemi \& Ani, 2012). The transesterification reaction requires three moles of alcohol for each mole of triglyceride to yield a product with three moles of esters and one mole of triglyceride. The larger the oil/alcohol molar ratio is (1:5-1:9), the higher the conversion of triglycerides into esters and the shorter the time necessary for the reaction to proceed are. Also, the transesterification is reversible. The use of reagents in excess (alcohol) ensures that the reaction shifts toward the products.

The transesterification is very sensitive to the effects of alcohol, oil/alcohol molar ratio, catalyst type and quantity, stirring and mixing system, process temperature, and reaction time (Stamenkovic et al., 2007). Over the last decades, a number of authors have reported on the transesterification of ricin oil. At large, literature has described how the physicochemical variables affect this transesterification. Only a few works have dealt with the influence of mechanical variables on this type of reaction, which directly impact the stirring and mixing processes and have a fundamental role in reaction efficiency (Brásio et al., 2011; Kiliç et al., 2013; Reyes et al., 2010; Silva et al., 2009). The effective use of a stirring system depends on impeller type, angular velocity, reactor geometry, fluid properties, and reaction features (Brásio et al., 2011; Frascari et al., 2009). Stirring is a determining factor in biodiesel production process, since in conventional processes, at extreme reaction conditions, it is not possible to obtain acceptable yields by regulatory agencies of fuels.

It is noteworthy that the study of the effect of stirring has the aim to provide better conversions and reduce costs associated with reaction time and use of chemicals. This type of study is underexploited in the literature applied to transesterification reaction. Several studies have focused on the reaction kinetics using magnetic stirrers. These works, however, have not provided relevant data for performing industrial equipment designs. Therefore, the study on the use of different impellers in biodiesel production process is critical in the decision-making stage during the implementation of an industrial project.

In this context, this work aimed to study how some stirring parameters (impeller type, presence 
and absence of deflection, and stirring rate) impact biodiesel production from castor oil. This work also examined other process variables such as reaction time, temperature, oil/alcohol molar ratio, and catalyst. A fractional factorial design helped to analyze the influence of the assessed variables and their binary interactions on biodiesel production, to determine the best operational/reaction conditions to obtain the desired biodiesel.

\section{MATERIALS AND METHODS}

This work has investigated how physicochemical and mechanical variables affect biodiesel production by transesterification via methylic route, with the goal of proposing the use of highperformance equipment that maximizes the biodiesel output, whist minimizing the reaction time and costs. Physical variables like reaction time and temperature were also assessed. Also, stirring variables, namely, impeller type (impeller dimensions are shown on Table 1), presence or absence of deflection, and stirring rate were examined. All conditions were evaluated in order to improve mixing of the reagents (homogenization) and minimize the formation of vortices. The quality of the oil and the resulting biodiesel was analyzed on the basis of the existing regulations issued by the National Agency of Petroleum, Natural Gas, and Biofuels (ANP, Brazil).

\subsection{Materials}

For the transesterification reactions, commercially available castor oil (SUCROQUÍMICA), methanol PA (Synth), sodium hydroxide and potassium hydroxide PA (Synth), and magnesium sulfate (Dinâmica Ltda) were employed. The reactions were conducted in a stirring tank reactor

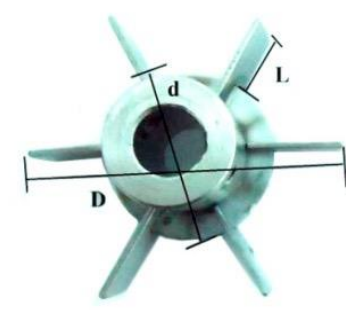

(a)

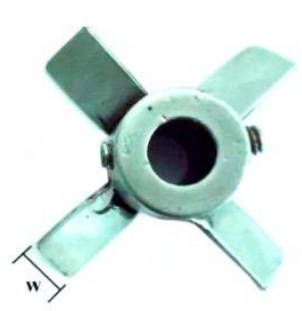

(b)
Figure 1. Impeller geometry: turbine (a) and inclined blade (b).

(TECNAL/TE 2003/02) and a thermostatic bath (TECNAL/TE 184). Gas chromatography analysis was carried out on a VARIAN chromatograph (model CP 3800). Figure 1 shows the geometry and dimensions of the impellers.

\subsection{Methods}

For the transesterification process, a 1.5-L batch reactor coupled to a thermostatic bath was employed. This arrangement allowed for temperature control throughout the reactions. Physicochemical analysis aided the characterization of the castor oil and the resulting biodiesel in terms of viscosity, density, acidity index, and moisture content, according to ASTM D445, D4052, D664, and $\mathrm{D} 6304$ guidelines, respectively.

\subsubsection{Experimental design}

To optimize biodiesel production from castor bean oil, a $2^{7-2}$ fractional factorial design was employed. The main response was the biodiesel yield. The adopted variables and levels were as follows: oil/methanol molar ratio of $1: 5$ or $1: 7$; temperature of $25^{\circ} \mathrm{C}$ (close to room temperature)

Table 1. Impellers dimensions.

\begin{tabular}{c|ccccc}
\hline \multirow{2}{*}{ Impeller } & \multicolumn{5}{|c}{ Impeller Dimensions } \\
\cline { 2 - 6 } & Number of Blades & $\begin{array}{c}\text { Impeller Diameter } \\
(D / \mathrm{cm})\end{array}$ & $\begin{array}{c}\text { Disc Diameter } \\
(d / \mathrm{cm})\end{array}$ & $\begin{array}{c}\text { Width } \\
(\mathrm{w} / \mathrm{cm})\end{array}$ & $\begin{array}{c}\text { Lenght } \\
(\mathrm{L} / \mathrm{cm})\end{array}$ \\
\hline Inclined Blades & 4 & 6.7 & 2.0 & 1.2 & 2.4 \\
Turbine & 6 & 5.0 & 3.3 & 1.0 & 1.2 \\
\hline
\end{tabular}


or $50{ }^{\circ} \mathrm{C}$ (a temperature closer to the boiling point of methanol); a higher stirring rate of $500 \mathrm{rpm}$ (because higher rotations improve contact between the reactants) or a lower stirring rate of $300 \mathrm{rpm}$; sodium hydroxide or potassium hydroxide at a concentration of $0.8 \% \mathrm{w} / \mathrm{w}$ (oil) as catalyst; reaction times of 15 or $30 \mathrm{~min}$; turbine or inclined-flat-blade impeller; and presence or absence of deflection. All experiments were performed in duplicate.

\subsubsection{Biodiesel production}

The transesterification reaction was conducted according to the procedure described in the preview sections. At the end of the reaction, the mixture was transferred to a separating funnel and allowed to rest for phase separation. The phases separated spontaneously in all reaction assays. The upper and lower phases were rich in biodiesel and glycerin, respectively. The biodiesel was washed three times with 0.7-M aqueous $\mathrm{H}_{2} \mathrm{SO}_{4}$, followed by two washings with distilled water, to adjust the $\mathrm{pH}$ and to remove tri-, di-, and monoacylglycerides as well as impurities like unreacted oil and alcohol, glycerin, and catalyst, among others. Next, the purified biodiesel was submitted to drying with approximately two grams of magnesium sulfate (dessicant), for an average of $30 \mathrm{~min}$, to remove moisture acquired along the washing steps. Finally, the biodiesel samples were filtered and analyzed by gas chromatography, to determine the reaction yield.

\subsubsection{Reaction yields}

A gas chromatograph equipped with a flame ionization detector and a $2.2-\mathrm{m}$ capillary column helped to determine the reaction yield, the percentage of castor oil conversion into biodiesel. The detector and injector temperatures were 250 and $240{ }^{\circ} \mathrm{C}$, respectively; the oven temperature was programmed to rise from 150 to $260{ }^{\circ} \mathrm{C}$ at a heating rate of $10{ }^{\circ} \mathrm{C} / \mathrm{min}$. Glycerol trioctanoate (tricapryllin) was the internal standard; high-purity hydrogen gas (99.95\%) was the carrier gas. The injection volume was $1.0 \mu \mathrm{L}$. The biodiesel yield was calculated by means of Equation 1 and the experimental error obtained was, for all experiments, below $5.00 \%$.
Yield $=\frac{\mathrm{M}_{I S} \times \mathrm{A}_{\mathrm{B}}}{\mathrm{A}_{/ S} \times \mathrm{M}_{\mathrm{B}}} \times \mathrm{F}_{\mathrm{C}}$

Where:

$\mathrm{M}_{\mathrm{IS}}=$ Mass of the internal standard tricapryllin (used to prepare the solution for injection);

$A_{B}=$ Area corresponding to biodiesel (peaks corresponding to biodiesel in the chromatogram);

$A_{p}=$ Area corresponding to the internal standard (peaks corresponding to tricapryllin in the chromatogram);

$M_{B}=$ Mass of biodiesel (used to prepare the solution for injection);

$\mathrm{F}_{\mathrm{C}}=$ Correction factor (calculated from standard biodiesel, for a $100 \%$ conversion).

\section{RESULTS AND DISCUSSIONS}

\subsection{Analysis of the physicochemical properties of castor oil and biodiesel}

Table 2 shows the physicochemical properties of castor oil, compared with literature values, and biodiesel. To be commercially viable, biodiesel must comply with certain regulation requirements. Analyses of the final product (purified biodiesel) aided its characterization. According to Table 2, viscosity and moisture contents of the biodiesel obtained in this work were below literature values. High viscosity is typical of castor oil, its distinct molecular structure favors intermolecular interactions, such as dipole-dipole forces and hydrogen bonds, because a hydroxyl group is present in the twelfth carbon of ricinoleic acid, which is the major component of castor oil. Blending of ricin biodiesel with other vegetable oils or mineral diesel reduces biofuel viscosity. The high moisture content in the biodiesel obtained herein might result from ineffective drying during the purification.

\subsection{Influence of process variables and their main interactions}

This work analyzed the effect of each variable and the impact of binary interactions in terms of biodiesel yield (oil conversion to methyl esters), 
Table 2. Physicochemical properties of castor and biodiesel oils.

\begin{tabular}{|c|c|c|}
\hline \multicolumn{3}{|c|}{ Castor Oil } \\
\hline Properties & Values & Literature Values \\
\hline Viscosity (cst or $\mathrm{mm}^{2} / \mathrm{s}$ ) & 242.22 & 289.57 (Encinar et al., 2012) \\
\hline Density $\left(\mathrm{g} / \mathrm{cm}^{3}\right)$ & 0.957 & 0.965 (Kiliç et al., 2013) \\
\hline Saponification Number (unity) & 220.04 & 182 (Kiliç et al., 2013) \\
\hline Acid Value (mgKOH / g) & 0.65 & 2.1 (Dias et al., 2013) \\
\hline Moisture (\%) & 0.26 & 0.2 (Encinar et al., 2012) \\
\hline \multicolumn{3}{|c|}{ Biodiesel } \\
\hline Properties & Values & ANP range (ANP, 2012) \\
\hline Viscosity $\left(\mathrm{mm}^{2} / \mathrm{s}\right)$ & 15.4 (ASTM, 2013a) & $3.0-6.0$ \\
\hline Density $\left(\mathrm{g} / \mathrm{cm}^{3}\right)$ & 0.90 (ASTM, 2011) & $0.85-0.90$ \\
\hline Acid Value (mgKOH / g) & 0.23 (ASTM, 2013b) & $<0.50$ \\
\hline Moisture (\%) & 0.95 (ASTM, 2007) & 0.35 \\
\hline
\end{tabular}

with a $95 \%$ confidence. The following variables afforded significant effects: catalyst, stirring rate, impeller type, and oil/methanol molar ratio. The experiments were carried out randomly. Table 3 lists all the assays according to the $2^{7-2}$ fractional factorial design and the mean yield of each duplicate. Table 4 summarizes the estimated effects of the variables and their binary interactions, pure error, and the results of Student and $p$-value tests. The main negative effects, catalyst and impeller type, provided a lower reaction yield. The top positive effects, stirring rate and oil/alcohol molar ratio, contributed to achieve an increased reaction yield. The order of significance of the effects on transesterification were: catalyst type > impeller type > stirring rate > oil/alcohol molar ratio, irrespective of the algebraic sign. Interactions (3) and (7), (3) and (4), and (3) and (6) were significant and negative. This indicates that, as long as the individual trends of each main variable (stirring rate, temperature, oil/alcohol molar ratio, and time at the lower stirring rate) remain in order of priority, the result is a lower transesterification yield. On the basis of this statistical analysis, the reaction yield should rises upon inversion of the trend of the main variables that were less significant than the interactions. The effect due to interaction between variables (1) and
(3) was significant and positive. Therefore, conservation of the individual trends of the main variables should raise the reaction yield.

The variable that led to the largest estimate effect (according to the experimental design) was the catalyst. $\mathrm{NaOH}$ was the ideal catalyst for biodiesel production from castor oil. The mechanical variables turbine impeller and high stirring rate $(500 \mathrm{rpm})$ also elicited higher reaction yields. No literature work has evaluated how impeller type influences biodiesel production. Herein, the application of turbine impeller aimed to produce mass transfer during the stirring process. Indeed, this type of impeller dissolved reagents and catalyst to a larger extent, which improved the yields. This is because high rotation increased the collision rate and the number of effective collisions (which favored the formation of the higher-energy activated complex for product formation), thereby raising the ester production rate. According to Reyes et al. (2010), the biodiesel conversion ratio clearly depends on the turbulence degree, and larger Reynolds numbers give higher conversion ratios. Li et al. (2013) also achieved similar results, that is, higher stirring rates improved product yield during the esterification-transesterification of soybean oil in the presence of solid catalysts. 
Table 3. Level of variables and biodiesel yield: $\mathrm{n}$ - experimental number; dup. - duplicate; I - impeller; $\mathrm{C}$ - chicanes; $\mathrm{A}$ - agitation velocity; $\mathrm{R}$ - molar ratio of oil/methanol; Cat - catalyst; $\mathrm{t}$ - reaction time; $\mathrm{T}$ - reaction temperature; $\mathrm{Y}$ (\%) - yield.

\begin{tabular}{|c|c|c|c|c|c|c|c|c|c|}
\hline \multirow{2}{*}{\multicolumn{2}{|c|}{$\begin{array}{c}\text { Run/ } \\
\text { (n. dup.) }\end{array}$}} & \multicolumn{7}{|c|}{ Variables } & \multirow{2}{*}{$\begin{array}{c}\text { Average Yield } \\
\text { (\%) }\end{array}$} \\
\hline & & \multirow{2}{*}{$\frac{\text { I }}{\text { TURBINE }}$} & \multirow{2}{*}{$\frac{\text { C }}{\text { WITHOUT }}$} & \multirow{2}{*}{$\frac{\text { A }}{300}$} & \multirow{2}{*}{$\frac{\mathbf{R}}{1: 5}$} & \multirow{2}{*}{$\frac{\text { Cat }}{\mathrm{NaOH}}$} & \multirow{2}{*}{$\begin{array}{l}\mathbf{T} \\
30\end{array}$} & \multirow{2}{*}{$\begin{array}{l}\mathbf{T} \\
50\end{array}$} & \\
\hline 1 & $1-1$ & & & & & & & & $99.3 \pm 1.0$ \\
\hline 2 & $2-1$ & BLADES & WITHOUT & 300 & $1: 5$ & $\mathrm{NaOH}$ & 15 & 25 & $88.4 \pm 4.7$ \\
\hline 3 & $3-1$ & TURBINE & WITH & 300 & $1: 5$ & $\mathrm{NaOH}$ & 15 & 25 & $94.3 \pm 3.1$ \\
\hline 4 & $4-1$ & BLADES & WITH & 300 & $1: 5$ & $\mathrm{NaOH}$ & 30 & 50 & $89.5 \pm 4.5$ \\
\hline 5 & $5-1$ & TURBINE & WITHOUT & 500 & $1: 5$ & $\mathrm{NaOH}$ & 15 & 50 & $92.1 \pm 1.1$ \\
\hline 6 & $6-1$ & BLADES & WITHOUT & 500 & $1: 5$ & $\mathrm{NaOH}$ & 30 & 25 & $93.1 \pm 2.5$ \\
\hline 7 & $7-1$ & TURBINE & WITH & 500 & $1: 5$ & $\mathrm{NaOH}$ & 30 & 25 & $88.9 \pm 3.8$ \\
\hline 8 & 8-1 & BLADES & WITH & 500 & $1: 5$ & $\mathrm{NaOH}$ & 15 & 50 & $96.7 \pm 2.0$ \\
\hline 9 & $9-1$ & TURBINE & WITHOUT & 300 & $1: 7$ & $\mathrm{NaOH}$ & 15 & 25 & $92.4 \pm 1.1$ \\
\hline 10 & $10-1$ & BLADES & WITHOUT & 300 & $1: 7$ & $\mathrm{NaOH}$ & 30 & 50 & $99.1 \pm 1.2$ \\
\hline 11 & $11-1$ & TURBINE & WITH & 300 & $1: 7$ & $\mathrm{NaOH}$ & 30 & 50 & $97.9 \pm 3.0$ \\
\hline 12 & $12-1$ & BLADES & WITH & 300 & $1: 7$ & $\mathrm{NaOH}$ & 15 & 25 & $88.7 \pm 2.3$ \\
\hline 13 & $13-1$ & TURBINE & WITHOUT & 500 & $1: 7$ & $\mathrm{NaOH}$ & 30 & 25 & $99.3 \pm 0.2$ \\
\hline 14 & $14-1$ & BLADES & WITHOUT & 500 & $1: 7$ & $\mathrm{NaOH}$ & 15 & 50 & $92.1 \pm 0.8$ \\
\hline 15 & $15-1$ & TURBINE & WITH & 500 & $1: 7$ & $\mathrm{NaOH}$ & 15 & 50 & $97.1 \pm 0.2$ \\
\hline 16 & $16-1$ & BLADES & WITH & 500 & $1: 7$ & $\mathrm{NaOH}$ & 30 & 25 & $98.9 \pm 1.6$ \\
\hline 17 & $17-1$ & TURBINE & WITHOUT & 300 & $1: 5$ & $\mathrm{KOH}$ & 30 & 25 & $87.5 \pm 0.8$ \\
\hline 18 & $18-1$ & BLADES & WITHOUT & 300 & $1: 5$ & $\mathrm{KOH}$ & 15 & 50 & $77.5 \pm 0.4$ \\
\hline 19 & $19-1$ & TURBINE & WITH & 300 & $1: 5$ & $\mathrm{KOH}$ & 15 & 50 & $87.8 \pm 2.7$ \\
\hline 20 & $20-1$ & BLADES & WITH & 300 & $1: 5$ & $\mathrm{KOH}$ & 30 & 25 & $81.1 \pm 2.1$ \\
\hline 21 & $21-1$ & TURBINE & WITHOUT & 500 & $1: 5$ & $\mathrm{KOH}$ & 15 & 25 & $97.2 \pm 0.8$ \\
\hline 22 & $22-1$ & BLADES & WITHOUT & 500 & $1: 5$ & $\mathrm{KOH}$ & 30 & 50 & $90.7 \pm 2.1$ \\
\hline 23 & $23-1$ & TURBINE & WITH & 500 & $1: 5$ & $\mathrm{KOH}$ & 30 & 50 & $93.5 \pm 3.7$ \\
\hline 24 & $24-1$ & BLADES & WITH & 500 & $1: 5$ & $\mathrm{KOH}$ & 15 & 25 & $87.1 \pm 4.0$ \\
\hline 25 & $25-1$ & TURBINE & WITHOUT & 300 & $1: 7$ & $\mathrm{KOH}$ & 15 & 50 & $96.3 \pm 3.3$ \\
\hline 26 & $26-1$ & BLADES & WITHOUT & 300 & $1: 7$ & $\mathrm{KOH}$ & 30 & 25 & $86.3 \pm 2.5$ \\
\hline 27 & $27-1$ & TURBINE & WITH & 300 & $1: 7$ & $\mathrm{KOH}$ & 30 & 25 & $91.4 \pm 1.1$ \\
\hline 28 & $28-1$ & BLADES & WITH & 300 & $1: 7$ & $\mathrm{KOH}$ & 15 & 50 & $87.3 \pm 1.1$ \\
\hline 29 & $29-1$ & TURBINE & WITHOUT & 500 & $1: 7$ & $\mathrm{KOH}$ & 30 & 50 & $86.2 \pm 3.1$ \\
\hline 30 & $30-1$ & BLADES & WITHOUT & 500 & $1: 7$ & $\mathrm{KOH}$ & 15 & 25 & $93.1 \pm 1.9$ \\
\hline 31 & $1-1$ & TURBINE & WITH & 500 & $1: 5$ & $\mathrm{KOH}$ & 15 & 25 & $89.6 \pm 0.7$ \\
\hline 32 & $32-1$ & BLADES & WITH & 500 & $1: 7$ & $\mathrm{KOH}$ & 30 & 50 & $87.9 \pm 2.3$ \\
\hline
\end{tabular}

Stamenkovic et al. (2007) and Noureddini and Zhu (1997) verified that higher stirring rates produced biodiesel within a shorter reaction time. Together, these facts attest to the importance of studying the stirring and mixing processes along biodiesel production.
The ideal reaction time for biodiesel production from castor oil was $30 \mathrm{~min}$. The reversibility of transesterification may favor reaction between the products, which form reactants after a prolonged reaction time. As a consequence, the yield of methyl esters is lower. In this sense, Falahati and Tremblay (2012) obtained an interesting result: 
Table 4. Main interaction effects, pure error, Student and p-values.

\begin{tabular}{|c|c|c|c|c|}
\hline Variables & Effects & Standard Deviation & $t(32)$ & p-value \\
\hline Mean & 91.54 & 0.30 & 303.38 & $<0.05$ \\
\hline (I) & -3.36 & 0.60 & -5.57 & $<0.05$ \\
\hline (C) & -0.84 & 0.60 & -1.39 & 0.1716 \\
\hline (A) & 2.46 & 0.60 & 4.08 & $<0.05$ \\
\hline (M) & 2.40 & 0.60 & 3.97 & $<0.05$ \\
\hline (c) & -5.41 & 0.60 & -8.96 & $<0.05$ \\
\hline$(t)$ & 0.80 & 0.60 & 1.32 & 0.1943 \\
\hline$(T)$ & 0.82 & 0.60 & 1.36 & 0.1811 \\
\hline $\mathrm{I} \times \mathrm{C}$ & 0.46 & 0.60 & 0.76 & 0.4490 \\
\hline$I \times A$ & 2.75 & 0.60 & 4.56 & $<0.05$ \\
\hline I $\times M$ & 1.28 & 0.60 & 2.12 & $<0.05$ \\
\hline $1 \times c$ & -1.50 & 0.60 & -2.49 & $<0.05$ \\
\hline $1 \times t$ & 1.20 & 0.60 & 1.99 & 0.0541 \\
\hline $\mathrm{IxT}$ & -0.28 & 0.60 & -0.46 & 0.6443 \\
\hline $\mathrm{C} \times \mathrm{A}$ & 0.25 & 0.60 & 0.41 & 0.6814 \\
\hline$C \times M$ & 0.10 & 0.60 & 0.16 & 0.8694 \\
\hline $\mathrm{Cxc}$ & -0.35 & 0.60 & -0.58 & 0.5659 \\
\hline$C x t$ & -0.68 & 0.60 & -1.13 & 0.2630 \\
\hline $\mathrm{CxT}$ & 1.41 & 0.60 & 2.34 & $<0.05$ \\
\hline$A \times M$ & -1.85 & 0.60 & -3.07 & $<0.05$ \\
\hline$A \times C$ & 1.40 & 0.60 & 2.33 & $<0.05$ \\
\hline$A \times t$ & -1.64 & 0.60 & -2.72 & $<0.05$ \\
\hline$A \times T$ & -2.24 & 0.60 & -3.71 & $<0.05$ \\
\hline$M \times c$ & -0.49 & 0.60 & -0.81 & 0.4192 \\
\hline$M \times t$ & 0.54 & 060 & 0.90 & 0.3742 \\
\hline$M \times T$ & -0.31 & 0.60 & -0.52 & 0.6010 \\
\hline
\end{tabular}

during shorter residence times, the non-reacted chemicals increased the internal pressure in the reactor, but the residence time did not affect the resulting biodiesel obtained from different sources. This information further highlights the result achieved with castor oil, because longer reaction times yielded larger conversion ratios.

According to the classic literature on biodiesel (Freedman et al., 1986), temperature plays an important role in biodiesel production. At room temperature and up to a certain time, the transesterification reaction will only reach equilibrium. However, reactions conducted at temperatures close to the boiling point of the alcohol give better outcomes (Murugesan et al., 2009). Based on the results of the present work, the ideal temperature for biodiesel production from castor bean oil is $50^{\circ} \mathrm{C}$, which is close to the boiling point of the alcohol. Bearing in mind that the optimized reaction time is $30 \mathrm{~min}$, our results resemble those that literature works consider ideal for transesterification reactions. 


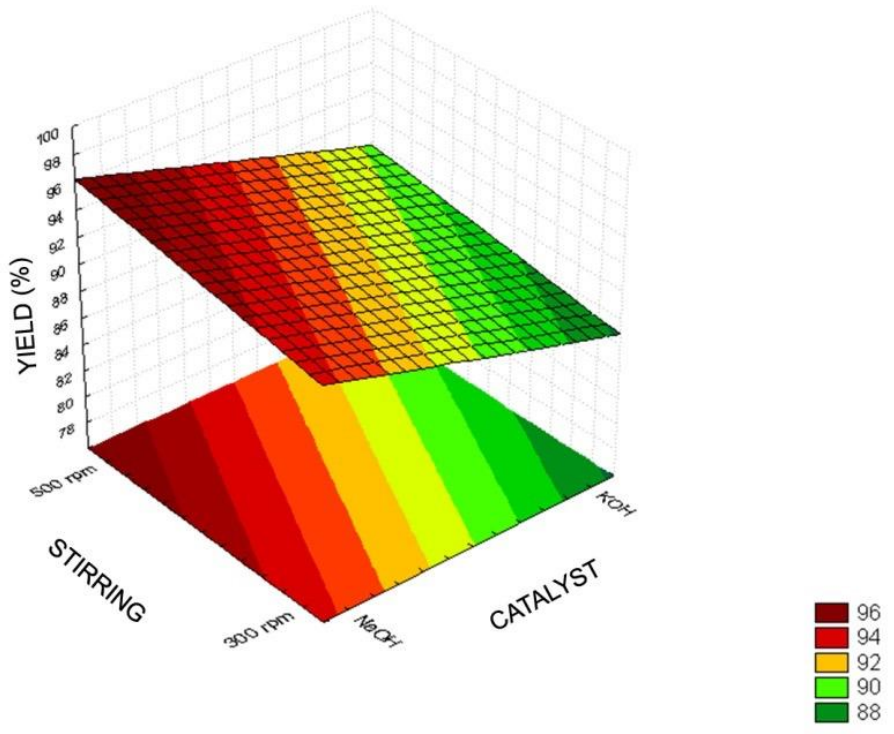

Figure 2. Response surface of yield of biodiesel production as a function of catalyst type and stirring rate. Catalyst concentration $=0.8 \%$.

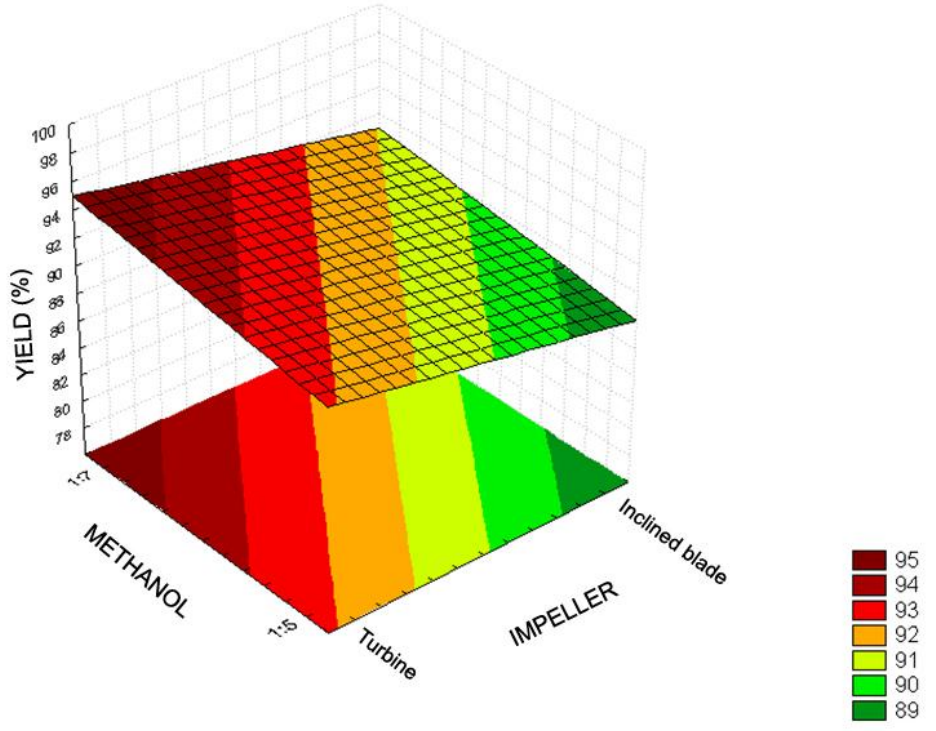

Figure 3. Response surface of yield of biodiesel production as a function of molar ratio of oil/methanol and impeller type.

This work analyzed the yield of biodiesel production from castor oil in the presence of two catalysts, $\mathrm{KOH}$ or $\mathrm{NaOH}$, under various operational conditions. Figure 2 illustrates the response surface for the interaction between the catalyst and the stirring rate. Figure 3 shows the surface response for the interaction between the impeller geometry and the oil/methanol molar ratio. Stirring the reactional mixture at a high rotation speed, 500 rpm, significantly increased the final biodiesel yield.
Therefore, the impeller geometry, turbine or inclined-flat-blade impeller, was one of the most significant variables for achievement of higher biodiesel yield. Here, turbine impeller provided higher conversion ratios in the presence of $\mathrm{NaOH}$ as catalyst. The oil/methanol molar ratio 1:7 provided better biodiesel yields than the oil/methanol molar ratio of 1:5. Molar ratios ranging between $1: 7$ and 1:9 afforded higher biodiesel yields. 


\section{CONCLUSIONS}

This work investigates how stirring variables affect biodiesel production from castor oil via methyl transesterification and alkaline catalysis. The $2^{7-2}$ fractional experimental design proved to be an excellent tool to evaluate the main effects of the variables and the interaction between them. This design determined the variables that favored the transesterification process.

The variables that impacted the transesterification reaction most significantly were the stirring rate, impeller type, catalyst type, and oil/alcohol molar ratios. The other studied parameters did not influence this process significantly. Considering the variables and the studied ranges, the best conditions to produce methyl biodiesel from castor oil via alkaline transesterification were: turbine impeller, absence of deflection, stirring rate of $500 \mathrm{rpm}$, oil/alcohol molar ratio of $1: 7, \mathrm{NaOH}$ as catalyst, reaction time of $30 \mathrm{~min}$, and temperature of $50 \stackrel{\circ}{\circ}$. Proper design of biodiesel production units require relevant laboratory data. Thus, this study shows that the choice of appropriate agitation system in the production can impact economic viability.

\section{ACKNOWLEDGEMENTS}

The authors thank Coordination for the Development of Higher Education Personnel (CAPES) for providing a scholarship to the graduate student of the Chemical Engineering Graduate Program at Federal University of Alagoas.

\section{REFERENCES}

Adewale, P.; Dumont, M.; Ngadi, M. Recent trends of biodiesel production from animal fat wastes and associated production techniques. Renewable \& Sustainable Energy Reviews, v. 45, p. 574-588, 2015.

http://dx.doi.org/10.1016/j.rser.2015.02.039
Almeida, V. F.; García-Moreno, P. J.; Guadix, A.; Guadix, E. M. Biodiesel production from mixtures of waste fish oil, palm oil and waste frying oil: Optimization of fuel properties. Fuel Processing Technology, v. 133, p. 152-160, 2015.

http://dx.doi.org/10.1016/i.fuproc.2015.01.041

ASTM - American Society for Testing and Materials. D 445: Standard test method for kinematic viscosity of transparent and opaque liquids(and calculation of dynamic viscosity), 2013a.

ASTM - American Society for Testing and Materials. D 664: Standard test method for acid number of petroleum products by potentiometric titration, 2013b.

ASTM - American Society for Testing and Materials. D 4052: Density and relative density of liquids by digital density meter, 2011.

ASTM - American Society for Testing and Materials. D 6304: Test method for determination of water in petroleum products, lubricating oils, and additives by colorimetric Karl Fisher titration, 2007.

ANP - Agência Nacional do Petróleo, Gás Natural e Biocombustíveis. Resolução no 14, de 11.05.2012. Available at: <http://www.anp.gov.br/ > . Accessed in: 11/10/2013.

Atadashi, I. M.; Aroua, M. K.; Abdul Aziz, A. R.; Sulaiman, N. M. N. The effects of catalysts in biodiesel production: A review. Journal of Industrial and Engineering Chemistry, v. 19, p. 1426, 2013. http://dx.doi.org/10.1016/i.jiec.2012.07.009

Barbosa, D. C.; Serra, T. M.; Meneghetti, S. M. P.; Meneghetti, M. R. Biodiesel production by ethanolysis of mixed castor and soybean oils. Fuel, v. 89, p. 3791-3794, 2010. http://dx.doi.org/10.1016/j.fuel.2010.07.016

Baron, A. M.; Barouh, N.; Barea, B.; Villeneuve, P.; Mitchell, D. A.; Krieger, N. Transesterification of castor oil in a solvent-free medium using the lipase from Burkholderia cepacia LTEB11 immobilized on a hydrophobic support. Fuel, v. 117, p. 458-462, 2014. http://dx.doi.org/10.1016/j.fuel.2013.09.065 
Brásio, A. S. R.; Romanenko, A.; Santos, L. O.; Ferandes, N. C. P. Modeling the effect of mixing in biodiesel production. Bioresource Technology, v. 102(11), p. 6508-6514, 2011.

http://dx.doi.org/10.1016/i.biortech.2011.03.090

Çetinkaya, M.; Karaosmanoglu, F. Optimization of base-catalyzed transesterification reaction of used cooking oil. Energy \& Fuels, v. 18(6), p. $1888-$ 1895, 2004. http://dx.doi.org/10.1021/ef049891c

Dias, J.M.; Araújo, J.M.; Costa, J.F.; Alvim Ferraz, M.C.M.; Almeida, M.F. Biodiesel production from raw castor oil. Energy, v. 53, p. 58-66, 2013. http://dx.doi.org/10.1016/i.energy.2013.02.018

Encinar, J. M.; González, J. F.; Pardal, A. Transesterification of castor oil under ultrasonic irradiation conditions. Preliminary results. Fuel Processing Technology, v. 103, p. 9-15, 2012. http://dx.doi.org/10.1016/i.fuproc.2011.12.033

Falahati, H.; Tremblay, A. Y. The effect of flux and residence time in the production of biodiesel from various feedstocks using a membrane reactor. Fuel, v. 91(1), p. 126-133, 2012.

http://dx.doi.org/10.1016/i.fuel.2011.06.019

Ferella, F., Di Celso, G. M.; De Michelis, I.; Stanisci, V.; Veglió, F. Optimization of the transesterification reaction in biodiesel production. Fuel, v. 89, p. 36-42, 2010.

http://dx.doi.org/10.1016/i.fuel.2009.01.025

Frascari, D.; Zuccaro, M.; Paglianti, A.; Pinelli, D. Optimization of mechanical agitation and evaluation of the mass-transfer resistance in the oil transesterification reaction for biodiesel production. Industrial \& Engineering Chemistry Research, v. 48, p. 7540-7549, 2009.

http://dx.doi.org/10.1021/ie900283j

Freedman, B.; Butterfield R.O.; Pryde E. H. Transesterification kinetics of soyabean oil. Journal of American Oil Chemistry Society, v. 63, p. 13751380, 1986. http://dx.doi.org/10.1007/BF02679606

Hincapié, G.; Mondragón, F.; López, D. Conventional and in situ transesterification of castor seed oil for biodiesel production. Fuel, v. 90, p. 1618-1623, 2011.

http://dx.doi.org/10.1016/j.fuel.2011.01.027
Kiliç, M.; Urzun, B. B.; Putün, E.; Putün, A. E. Optimization of biodiesel production from castor oil using factorial design. Fuel Processing Technology, v. 111, p. 105-110, 2013. http://dx.doi.org/10.1016/i.fuproc.2012.05.032

Knothe, G.; Van Gerpen, J.; Krahl, J. The Biodiesel Handbook, AOCS Press, Peoria, Illinois, U.S.A (2005). http://dx.doi.org/10.1201/9781439822357

Leung, D. Y. C.; Wu, X.; Leung, M. K. H. A review on biodiesel production using catalyzed transesterification. Applied Energy, v. 87, p. 10831095, 2010.

http://dx.doi.org/10.1016/i.apenergy.2009.10.006

Li, Z.; Lin, P.; Wu, J. C. S.; Huang, Y.; Lin, K.; Wu, K. C.. A stirring packed-bed reactor to enhance the esterification-transesterification in biodiesel production by lowering mass-transfer resistance. Chemical Engineering Journal, v. 234, p. 9-15, 2013. http://dx.doi.org/10.1016/i.cej.2013.08.053

Motasemi, F.; Ani, F. N. A review on microwaveassisted production of biodiesel. Renewable \& Sustainable Energy Reviews, v. 16, p. 4719-4733, 2012. http://dx.doi.org/10.1016/j.rser.2012.03.069

Muniyappa, P. R., Brammer, S. C., Noureddini $\mathrm{H}$.. Improved conversion of plant oils and animal fats into biodiesel and co-product. Bioresource Technology, v. 56, p. 19-24, 1996.

http://dx.doi.org/10.1016/0960-8524(95)00178-6

Murugesan, A.; Umarani, C.;. Chinnusamy, T. R.; Krishnan, M.; Subramanian, R.; Neduzchezhain, N.. Production and analysis of bio-diesel from nonedible oils-A review. Renewable \& Sustainable Energy Reviews, v. 13, p. 825-834, 2009. http://dx.doi.org/10.1016/i.rser.2008.02.003

Noureddini, H.; Zhu, D. Kinetics of transesterification of soybean oil. Journal of American Oil Chemistry Society, v. 74, p. 1457 1463, 1997. http://dx.doi.org/10.1007/s11746-997$\underline{0254-2}$

Patil, P. D.; Deng, S. Optimization of biodiesel production from edible and non-edible vegetable oils. Fuel, v. 88, p. 1302-1306, 2009. http://dx.doi.org/10.1016/j.fuel.2009.01.016 
Reyes, J. F.; Malverde, P. E.; Melin, P. S.; De Brujin, J. P. Biodiesel production in a jet flow stirred reactor. Fuel, v. 89, p. 3093-3098, 2010.

http://dx.doi.org/10.1016/i.fuel.2010.06.002

Rodríguez-Guerrero, J. K.; Maciel-Filho, R.; Rosa, P. T. V. Production of biodiesel from castor oil using sub and supercritical ethanol: Effect of sodium hydroxide on the ethyl ester production. Journal of Supercritical Fluids, v. 83, p. 124-132, 2013. http://dx.doi.org/10.1016/i.supflu.2013.08.016

Sáez-Bastante, J.; Pinzi, S.; Jiménez-Romero, F. J.; Luque de Castro, M. D.; Priego-Capote, F.; Dorado, M. P. Synthesis of biodiesel from castor oil: Silent versus sonicated methylation and energy studies. Energy Conversion and Management, v. 96, p. 561-567, 2015.

http://dx.doi.org/10.1016/i.enconman.2015.03.019

Sánchez, N.; Sánchez, R.; Encinar, J. M.; González, J. F.; Martínez, G.. Complete analysis of castor oil methanolysis to obtain biodiesel. Fuel, v. 147, p. 95-99, 2015.

http://dx.doi.org/10.1016/i.fuel.2015.01.062

Sánchez-Cantú, M.; Pérez-Díaz, L. M.; PalaRosas, I.; Cadena-Torres, E.; Juárez-Amador, L.; Rubio-Rosas, E.; Rodríguez-Acosta, M.; Valente, J. S. Hydrated lime as an effective heterogeneous catalyst for the transesterification of castor oil and methanol. Fuel, v. 110, p. 54 - 62, 2013. http://dx.doi.org/10.1016/i.fuel.2012.07.075
Scholz, V.; Silva, J. N. Prospects and risks of the use of castor oil as a fuel. Biomass and Bioenergy, v. 32, p. 95-100, 2008.

http://dx.doi.org/10.1016/i.biombioe.2007.08.004

Silva, N. L.; Batistella, C. B.; Maciel Filho, R.; Maciel, M. R. W. Biodiesel production from castor oil: Optimization of Alkaline Ethanolysis. Energy Fuels, v. 23, p. 5636-5642, 2009.

http://dx.doi.org/10.1021/ef900403j

Stamenkovic, O. S.; Lazic, M. L.; Todorovic, Z. B.; Veljkovic, V. B.; Skala, D. U. The effect of agitation intensity on alkali-catalyzed methanolysis of sunflower oil. Bioresource Technology, v. 98, p. 2688-2699, 2007.

http://dx.doi.org/10.1016/j.biortech.2006.09.024

Vasudevan P. T., Briggs M. Biodiesel production -current state of the art and challenges. Journal of Industrial Microbiology and Biotechnology, v. 35, p. 421-430, 2008.

http://dx.doi.org/10.1007/s10295-008-0312-2 